\title{
SPECIES COMPOSITION AND SEASONAL PATTERNS OF BUTTERFLIES AT PERI- URBAN AREAS NEAR PUNE, MA- HARASHTRA, INDIA ${ }^{\dagger}$
}

\author{
Madhura Agashe *and Ankur Patwardhan \\ Annasaheb Kulkarni Deaprtment of Biodiversity, MES Abasaheb Garware College of Science and Pune-04 \\ † Presented at the 1st International Electronic Conference on Entomology (IECE 2021), 1-15 July 2021; \\ Available online: https://iece.sciforum.net/.
}

Citation: Agashe, M.; Patwardhan A. SPECIES COMPOSITION AND SEASONAL PATTERNS OF BUTTERFLIES AT PERI- URBAN AREAS NEAR PUNE, MAHARASHTRA, INDIA, in Proceedings of the 1st International Electronic Conference on Entomology, 1-15 July 2021, MDPI: Basel, Switzerland, doi:10.3390/IECE-10704

Published: 28 July 2021

Publisher's Note: MDPI stays neutral with regard to jurisdictional claims in published maps and institutional affiliations.

Copyright: () 2021 by the authors. Submitted for possible open access publication under the terms and conditions of the Creative Commons Attribution (CC BY) license (http://creativecommons.org/licenses /by/4.0/).

\begin{abstract}
Field investigations were conducted in the Saswad-Waghapur region near Pune city to study the species composition and seasonal variation of butterflies; and the impact of disturbances on them. The species diversity and abundances were noted using "Pollard Walk method" andthe disturbances at every site were quantitively measured in every season. Alpha and Beta diversity indices and correlation tests were performed to analyse the data. A total 1285 individuals representing 53 species and 37 genera belonging to 5 families were observed fromAugust 2020 to May 2021. Family Nymphalidae accounted for the most species richness (36\%) with 19 species, and Family Hesperiidae contributed the least (2\%) with just one species. Maximum unique species (10) were seen in the wild areas of grassland and least unique species (5) were seen in the impacted agricultural area. Shannon index $(\mathrm{H})$ values ranged from 2.64 to 2.74 indicating similar diversity at the three sites, whereas Margalef richness value ranged from 4.95 to 5.98 indicating higher species richness at the wild habitats.Species diversity was maximum during the monsoon months with many species such as Eurema hecabe (Common Grass yellow) and Ypthima Asterope (Common Threering) showingtheir peaks during this period. A steady decline was observed from the end of December extending till summer with few species like Lampides boeticus (Pea blue) showing their peaksduring winter. Disturbances such as Fire, Grazing and construction activities played a significant role in determining the species composition at various sites. Thus, the present investigation provided insight into the butterflies of Saswad-Waghapur region and the effect ofanthropogenic activities onthem.
\end{abstract}

Keywords: Butterfly Diversity; Species Composition; Disturbance index; Seasonal Patterns; Grasslands 